\title{
Catalog Mathematischer Modelle. Connessioni tra testo, rappresentazione grafica e descrizione analitica
}

\author{
Martino Pavignano \\ Caterina Cumino \\ Ursula Zich
}

Abstract

II contributo analizza il Catalog Mathematischer Modelle, edito da Schilling nel 1903, nella sua duplice accezione di catalogo: di modelli matematici e di immagini dei modelli stessi. ll lavoro è un primo esito della lettura critica di una fonte grafico/testuale/analitica avviata con un approccio interdisciplinare, che indaga i modelli fisici come linguaggio geometrico, tattile e visivo comune all'Architettura e alla Matematica.

Il catalogo rappresentò, per la vendita di modelli matematici, una tipologia di sistematizzazione nuova rispetto ad analoghi esempi editi nel ventennio precedente, proponendo una presentazione delle informazioni per famiglia e non solo per innovazione del prodotto da immettere sul mercato, mediando quindi il suo ruolo da catalogo di vendita a riferimento per la scelta degli ausili visivi per la didattica della Matematica.

II contesto socio-scientifico e l'analisi condotta, sostanzialmente visiva, non solo degli strumenti scelti per la rappresentazione, ma anche delle dinamiche editoriali, hanno portato a leggere criticamente il Catalogo come medium di comunicazione di risultati matematici con un risvolto visuale sul Pensiero Visivo nella materia di appartenenza, indagandone quindi le connessioni tra immagini scritte e parole disegnate, con uno sguardo verso l'oggetto reale, tra collezioni fisiche e digitali.

Parole chiave

Comunicazione della Geometria, modelli fisici, oggetti matematici, geometria delle superfici algebriche, Brill-Schilling.
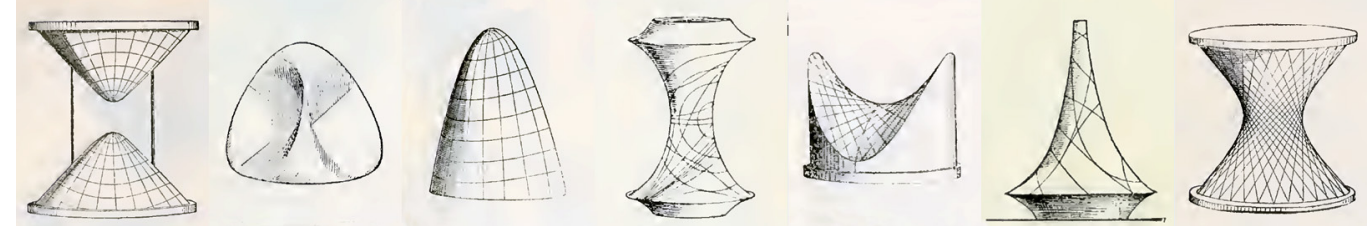

Catalog mathematischer Modelle
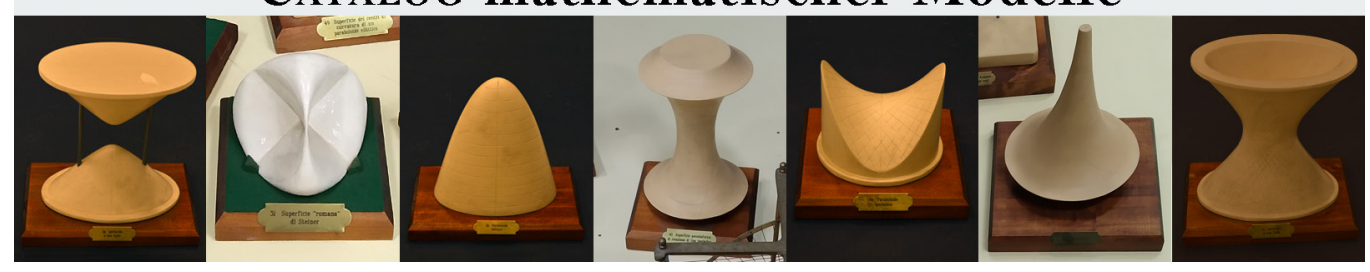


\section{Introduzione}

II contributo, parte di un progetto di ricerca multidisciplinare sull'analisi delle connessioni applicative tra Matematica e Architettura per mezzo del linguaggio comune della Geometria e con particolare focus sull'utilizzo dei modelli fisici nelle due discipline, propone un'analisi delle dinamiche comunicative relative all'edizione del 1903 del Catalog Mathematischer Modelle pubblicato da Martin Schilling. II catalogo fu uno strumento di promozione commerciale di ausili visuali per lo studio di problemi appartenenti alle aree più varie del pensiero matematico [Schilling 1903, p. III], con una tipologia di sistematizzazione nuova rispetto ad analoghi cataloghi editi nel ventennio precedente [I]. Si indagano le connessioni tra detti modelli e le loro rappresentazioni con immagini scritte e parole disegnate [2].

Fig. I. Pubblicità dell'editore Brill precedenti al 189: a) Archiv der Mathematik und Physik, 61, 336 1877; b) Mathematische Annalen, 15, 3-4, 1879; c) Mathematische Annalen, 18, 3, 1881; d) American Journal of Mathematics, 12 3. 1890 [Seidl et al. 2018 pp. $113,116,255,99]$.
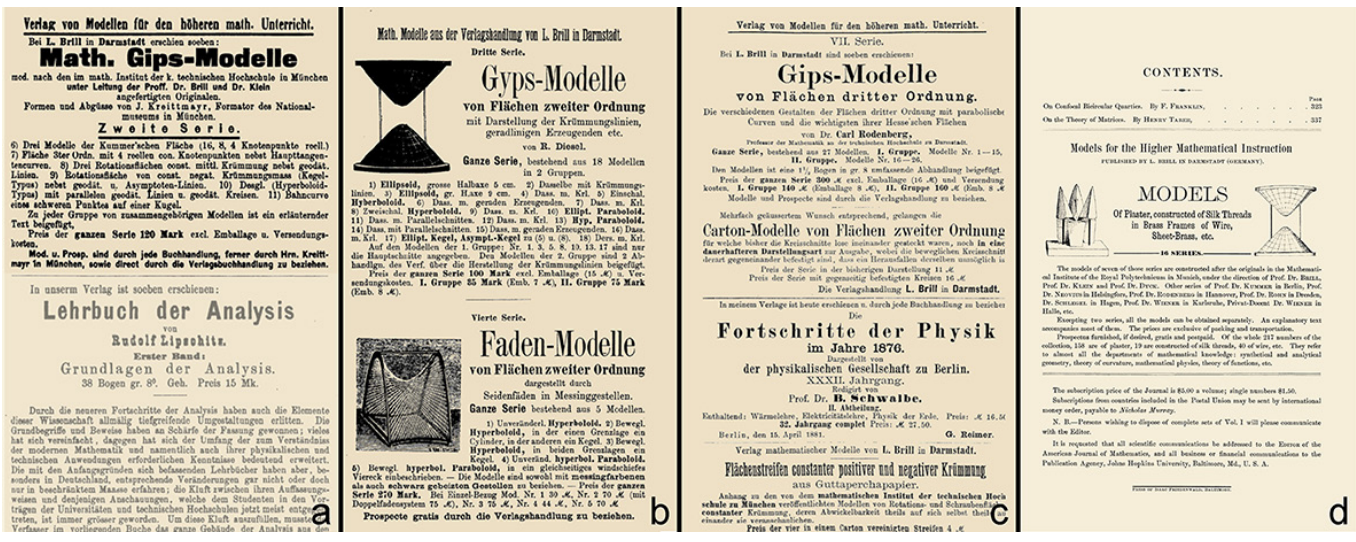

\section{Modelli geometrici}

In matematica, l'uso visivo di modelli spaziali risale almeno agli studi sui solidi platonici di Luca Pacioli [Betsch 20 I8, pp. 70, 7I], ma un primo riferimento all'impiego di modelli fisici risale al I 863 [Giacardi 2003, p. 25 I].

Verso la metà del XIX secolo, in particolare in Germania, i grandi progressi nello studio della Geometria indussero alla costruzione di modelli fisici di superfici algebriche, curve e altri oggetti matematici a partire dalle loro equazioni [Palladino e Palladino 200 I].

Uno dei fautori della produzione di modelli fu Felix Klein che, insieme ad Alexander von Brill, istituì a Monaco di Baviera un laboratorio per la progettazione e costruzione su scala artigianale [4]. I modelli erano costruiti con materiali poveri, ma il loro potenziale eidetico ne permetteva un uso finalizzato all'illustrazione di considerazioni o calcoli molto complessi, difficilmente descrivibili in termini di semplice linguaggio [Gay 2000, pp. 43-52], materializzando un costrutto immateriale di idee, connettendo il sistema astratto di segni codificati che li potevano descrivere ad un artefatto tangibile [Seidl 20।8, p. 20].

Secondo Klein erano un utile ausilio visivo [Giacardi 20I5], per mostrare i progressi della ricerca e per stimolare nuove indagini [Klein |872]. II modello non era fine a sé stesso, ma funzionava come una procedura epistemica: con la sua produzione e le relazioni con la famiglia di oggetti a cui apparteneva, indicava nuovi tipi di conoscenza [Friedman 20 I 8]. Inoltre, per Klein l'intuizione spaziale era fondamentale anche nel processo di modernizzazione dell'insegnamento della Matematica, per "rafforzare la capacità di pensare in tre dimensioni e l'abitudine al ragionamento funzionale" e per migliorare la formazione degli insegnanti, attraverso seminari di Matematica ed esercizi di Disegno e costruzione di modelli [Mattheis 2019, p. 93; Rowe 1985, p. 139]. Le potenzialità dei modelli apparvero presto evidenti e, al fine di diffonderne la vendita, fu fondata la casa editrice Ludwig Brill di Darmstadt, che predispose un catalogo per la loro promozione [Giacardi 2003], promuovendolo su importanti riviste matematiche (fig. I). 
Nel 1899 alla Brill subentrò la Martin Schilling di Halle che proseguì la pubblicazione, a partire dalla sesta edizione del catalogo, mentre il lavoro di sistematizzazione delle varie serie di modelli venne portato avanti con la collaborazione scientifica di molti matematici, tra i quali Ludwig Wiener e Herman Wiener [Schilling 1903, p. III]. La diffusione dei modelli uscì anche dall'ambito matematico: molti di essi furono generatori di suggestioni compositive, soprattutto per architetti e designer delle Avanguardie [Bortot 2019; Greco et al. 20।8; Farinella e Baglioni 20 I7].

Negli anni Trenta del Novecento la produzione si esaurì la crescente astrazione e generalizzazione del pensiero matematico fece sì che gli oggetti di ricerca non potessero più essere visualizzati con modelli 3D. Solo verso la fine del XX secolo il concetto di visualizzazione in Matematica venne recuperato, grazie al progresso dell'Informatica, con immagini virtuali e quindi oggetti potenzialmente concreti [Palladino 2009] e una rinnovata attenzione alla "dimensione materiale delle idee" [Marchis 2008, p. 170]: nonostante l'evoluzione di linguaggi e metodi, è ancora essenziale poter sviluppare una immagine mentale di un oggetto matematico a partire da un esempio concreto [Apery 20I2].

\section{Catalogo Schilling 1903: analisi}

Per stessa dichiarazione di Schilling, il catalogo del 1903 si presenta come l'evoluzione del precedente con esplicita intenzione di organizzarne meglio i contenuti in due parti distinte. La Parte I presenta i modelli in ordine di pubblicazione, serie e numero, la Parte II li dispone in modo sistematico fornendo una panoramica rispetto ai loro contenuti matematici. II catalogo sostituisce quindi i precedenti divenendo struttura portante per i successivi costituendo una schedatura degli ausili tattili scientifici di cui sistematizza i dati (serie e numero al momento della prima pubblicazione, materiale, dimensione, prezzo, classificazione matematica) rendendone più accessibile la condivisione, per rendere univoche identificazione e connessioni tra i differenti contenuti specifici delle sezioni. La differenza tra le due è ulteriormente sottolineata dalle scelte di impaginato: I colonna di testo nella Parte I che presenta una unica immagine (fig. 2b); 2 colonne di testo nella Parte II, a eccezione delle poche righe di introduzione alla parte specifica (fig. 2c), con 78 immagini dei 321 modelli descritti e 2 immagini dei supporti degli stessi (80 in totale).

Fig. 2. Esempi di impaginato del Catalog Mathematischer Modelle, 1903.

a, b) Parte I, pp. 6I, 66

c, d) Parte II, pp. 79, 80
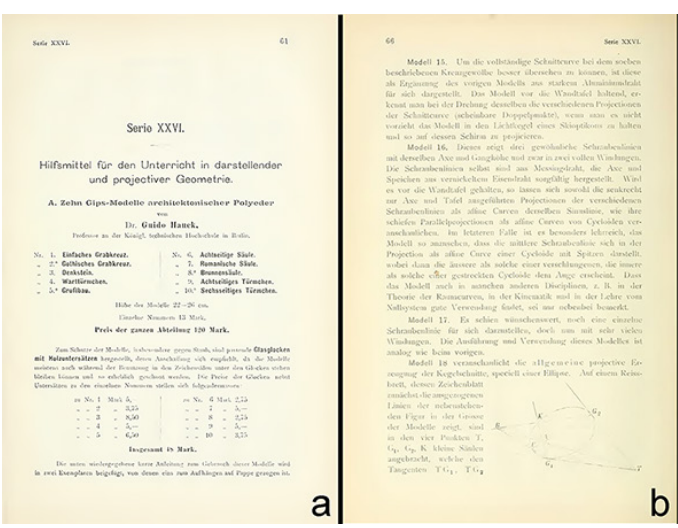

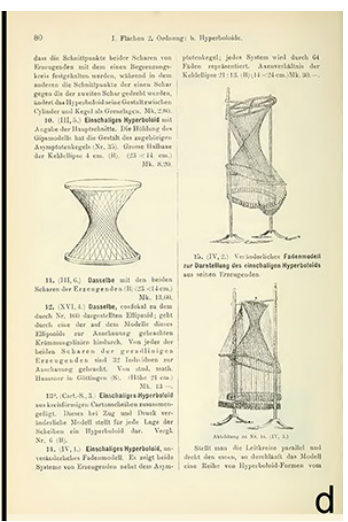

Il catalogo è stato analizzato non solo come tale [Vierling-Claassen 2007], ma come corpus di immagini di modelli indagandone le valenze semantiche e sintetiche, anche nel rapporto con l'oggetto reale che abbiamo verificato con la collezione della Biblioteca "G. Peano" del Dipartimento di Matematica dell'Università degli Studi di Torino [5]. 


\section{Da catalogo di modelli matematici a catalogo di immagini dei modelli matematici}

La lettura sistematica dell'apparato iconografico è stata impostata con una catalogazione che ne riassume le caratteristiche di: layout, descrizione testuale e correlazione con la stessa, valenze comunicative nella scelta di strumenti e codici della Rappresentazione. Nel costruire la schedatura, dove la qualità grafica della fonte di riferimento è parsa non adeguata alle considerazioni in oggetto si sono confrontate le illustrazioni delle edizioni successive e, nel caso di perfetta corrispondenza, si sono acquisite anche tali immagini (figg. 8a, 8b).

L'inserimento delle immagini in testo non segue uno schema rigido essendo inserite prima del nome del modello, all'interno della descrizione o nella pagina successiva; solo 9 hanno una didascalia.

II layout della Parte II è impostato su due colonne e delle 80 immagini presenti solo 2 le occupano entrambe, 5 sono di poco eccedenti (fig. 6c) e tutte le altre hanno dimensione inferiore alla larghezza della colonna lasciando ampi margini (fig. 3).

La fig. 4 sintetizza tutte le immagini estratte in sequenza dal catalogo mantenendo la stessa scala di riduzione per permetterne un confronto visivo diretto. I disegni non hanno esplicitata la scala di rappresentazione, ma nei relativi testi sono sempre espresse le dimensioni dei modelli.

La rappresentazione a p. 98 mostra due oggetti distinti appartenenti allo stesso gruppo di 8 modelli a filo. Le viste 3D mostrano i modelli come sintesi visiva e tattile della descrizione matematica di una curva gobba (filo metallico) in un sistema di riferimento definito dai tre

\begin{tabular}{|c|c|c|c|c|}
\hline $\begin{array}{l}80 \\
\text { Immagini } \\
\text { Images }\end{array}$ & $\begin{array}{l}1 \\
\text { Colonna } \\
\text { Column }\end{array}$ & $\begin{array}{l}2 \\
\text { Colonna } \\
\text { Column }\end{array}$ & $\begin{array}{l}\text { EXTRA } \\
\text { Extra Colonna } \\
\text { Extra Column }\end{array}$ & TOT \\
\hline $\begin{array}{l}\text { S } \\
\text { Singola } \\
\text { Single }\end{array}$ & 62 & & 4 & 66 \\
\hline $\begin{array}{l}\text { D } \\
\text { Doppia } \\
\text { Double }\end{array}$ & 2 & 1 & & 3 \\
\hline $\begin{array}{l}\text { G } \\
\text { Gruppo } \\
\text { Group }\end{array}$ & 3 & 1 & & 4 \\
\hline $\begin{array}{l}\text { M } \\
\text { Macchina per disegnare } \\
\text { Drawing Machine }\end{array}$ & 4 & & 1 & 5 \\
\hline $\begin{array}{l}\text { B } \\
\text { Base per modelli } \\
\text { Models Base }\end{array}$ & 2 & & & 2 \\
\hline TOT & 73 & 2 & 5 & 80 \\
\hline
\end{tabular}


Fig. 4. Matrice delle 80 illustrazioni della Parte II del Catalog

Mathematischer Modelle, 1903.

\section{$F=-\begin{array}{lll}-x & \times\end{array}$}

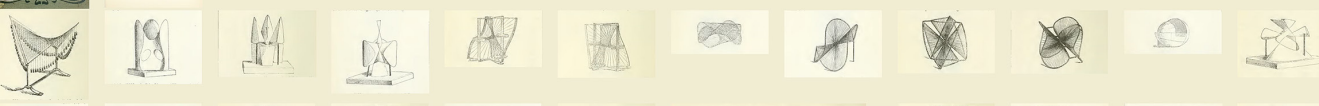

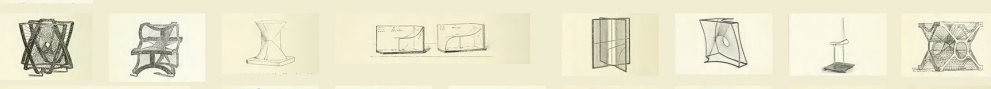

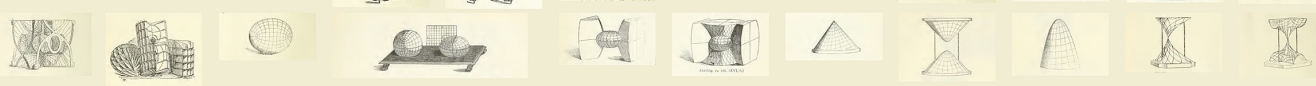

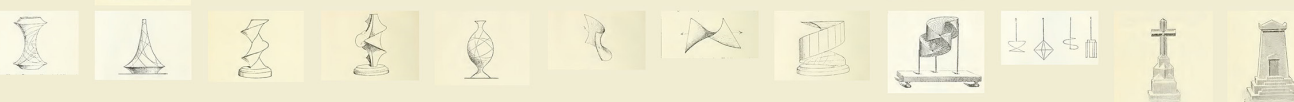

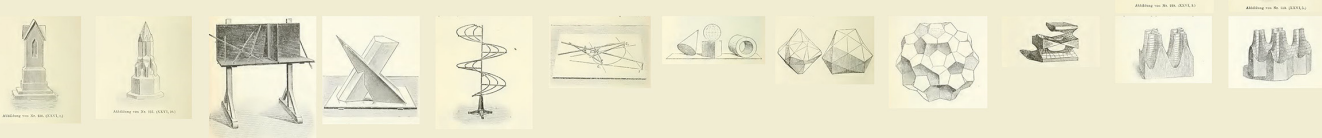

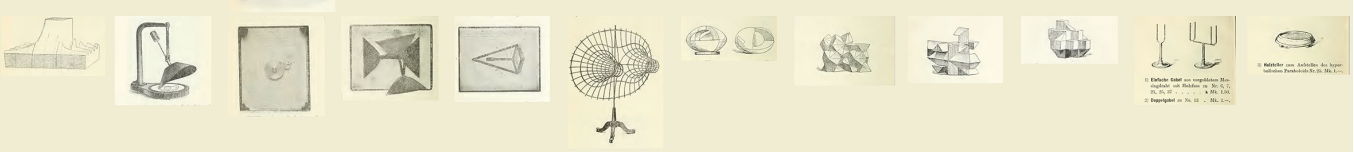

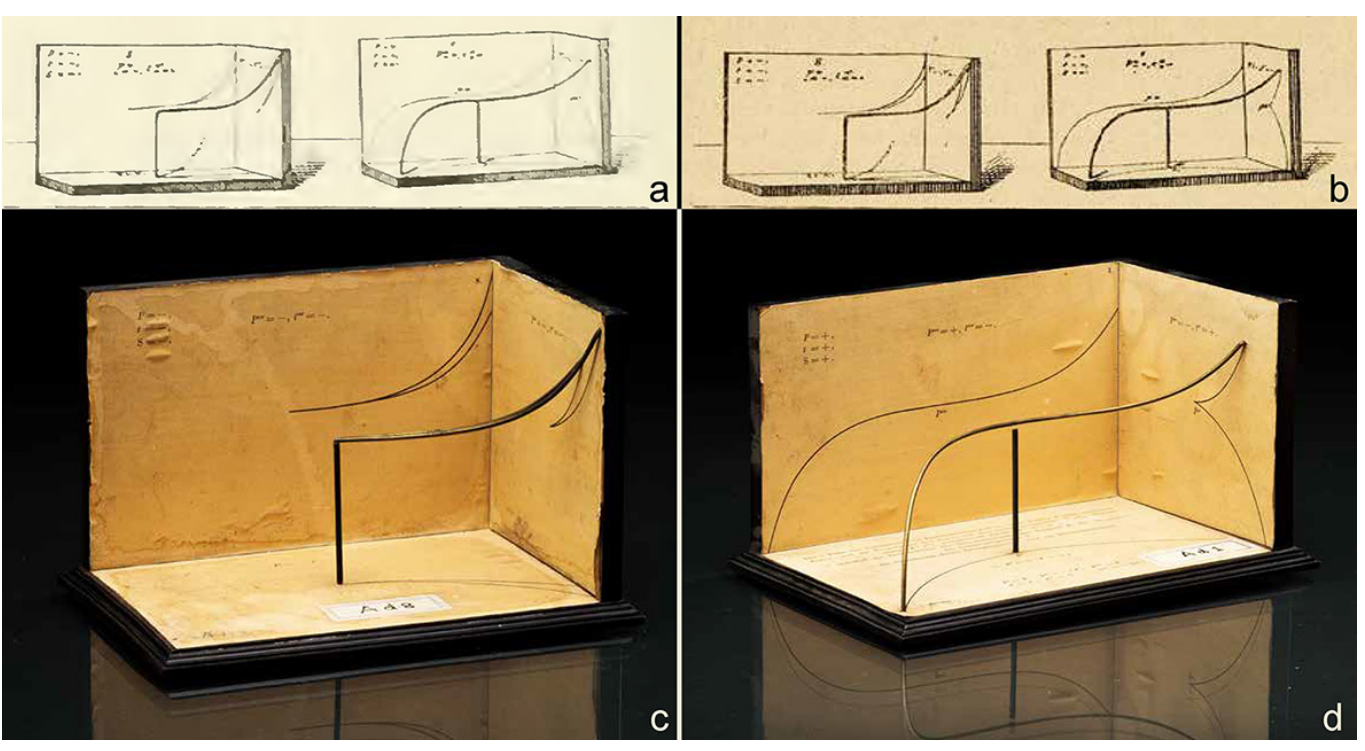

X $M M M$ $y^{2}$
Fig. 5. Curve gobbe in relazione alle rispettive proiezioni ortogonali:

) Schilling 1903, p. 98); b) Brill 1885, p. 38

c, d) fotografie dei relativi

modelli dalla collezione

dell Universita di Tubingen

[Seidl et al. 2018, pp. 278,

282]. 
piani ortogonali; la possibilità di muovere il proprio punto di vista e osservare la proiezione del filo sui piani rende il modello interattivo avviando una immediata correlazione tra singolarità della curva e singolarità delle sue proiezioni. Immagini fotografiche relative a modelli appartenenti a collezioni oggi visitabili in rete permettono di cogliere ulteriori dettagli dell'allestimento del filo rispetto ai piani che riportano non solo le proiezioni ortogonali sui tre piani ma anche testi e indicazioni analitiche (fig. 5).

I modelli XVI, I-3 sono rappresentati sul supporto ligneo con il quale vengono venduti come gruppo proprio per mantenerne le connessioni (fig. 6b). Altre 3 immagini di gruppi sono inserite in colonna a larghezza singola, vedi pp. 79, I 13 e I 02 (fig. 6a).

Le restanti 73 immagini sono inserite in colonna di testo e solo 3 contengono 2 rappresentazioni contemporaneamente: a pp. I | 8, I 30 troviamo rappresentazioni di 2 oggetti diversi riferibili alla stessa descrizione (fig. 7a), mentre a p. 126 l'immagine presenta due viste dello stesso oggetto, una in proiezione ortogonale e una tridimensionale, forse nellintenzione di mostrare la possibilità di smontare il modello per osservarne l'interno (fig. 7b).

Fig. 6. Esempi di impaginato: a) $X X \mid 1,1-3$, p. 102 ; b) $X V I, I-3, p .103$;

c) figure che occupano 10 spazio tra le colonne di testo e i margini laterali, p. 115 .
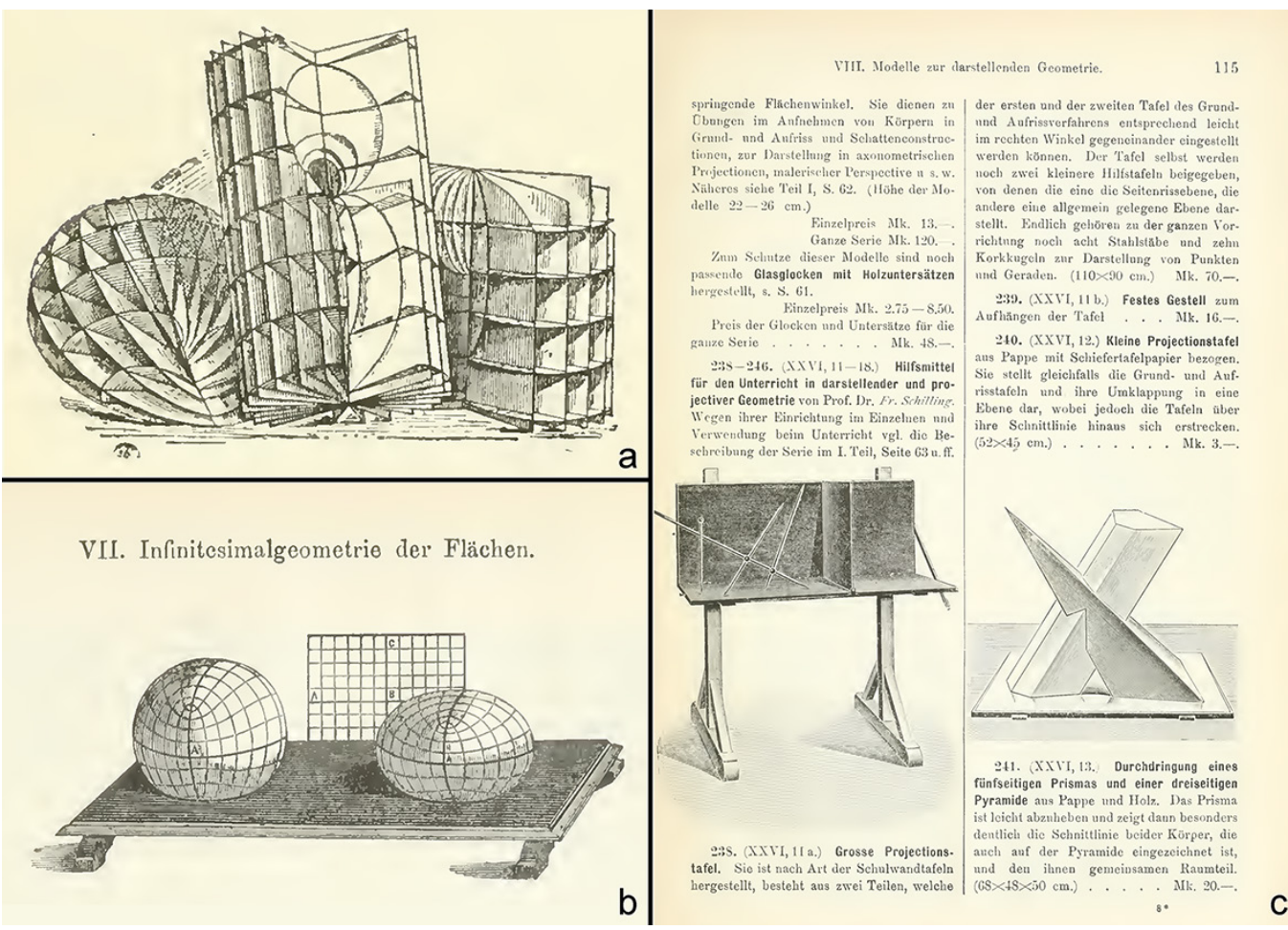

II solo modello XXVI, 18 è rappresentato due volte, una nella Parte I a p. 66 occupando 2/3 della colonna e una nella Parte II, a p. I I 6 (fig. 8a, 8c). La sua unicità nel catalogo trova possibile interpretazione nell'intenzione di illustrare "la generazione proiettiva generale di sezioni coniche, in particolare un'ellisse", ovvero il funzionamento della macchina per disegnare, andando oltre la mera descrizione materica. La descrizione tecnica (fig. 8b) si avvale di tipo di linee differenti e di lettere per individuare i punti e l'autore ricorda che, nell'intenzione progettuale della creazione e diffusione di modelli matematici come ausili visivi didattici, "quando si costruiscono i modelli, si presta particolare attenzione a garantire che le parti tecniche non oscurino l'idea matematica" [Schilling 1903, p. 67]. Invece, le indicazioni testuali di p. I I 6 (fig. 8c) sono essenziali e la prospettiva sintetizza tridimensionalità della macchina ed esito del suo utilizzo: le ombre evidenziano la volumetria della struttura e la totale assenza di quelle che la stessa proietterebbe sul foglio suggerisce di leggere l'immagine come 
Fig. 7. Immagini abbinate: a) $X V, 8-12, p .118$; b) VI, I, p. 126. rappresentazione sintetica, non descrittiva, simbolica nel privilegiare il contenuto e non necessariamente la sua perfetta corrispondenza con il reale: l'ombra dello strumento avrebbe fortemente limitato la lettura del suo prodotto in fase di utilizzo. Con queste intenzioni, in alcune occasioni (pp. 124, I25), è stata utilizzata la fotografia (fig. 8d), strumento ulteriormente implementato nelle successive edizioni.

Possiamo quindi distinguere rappresentazioni descrittive e simboliche, disegni geometricamente costruiti e non, viste 3D e piani di proiezione, fotografie e disegni costruiti come ricalco delle stesse offrendo un vasto panorama diversificato di immagini che concorrono a
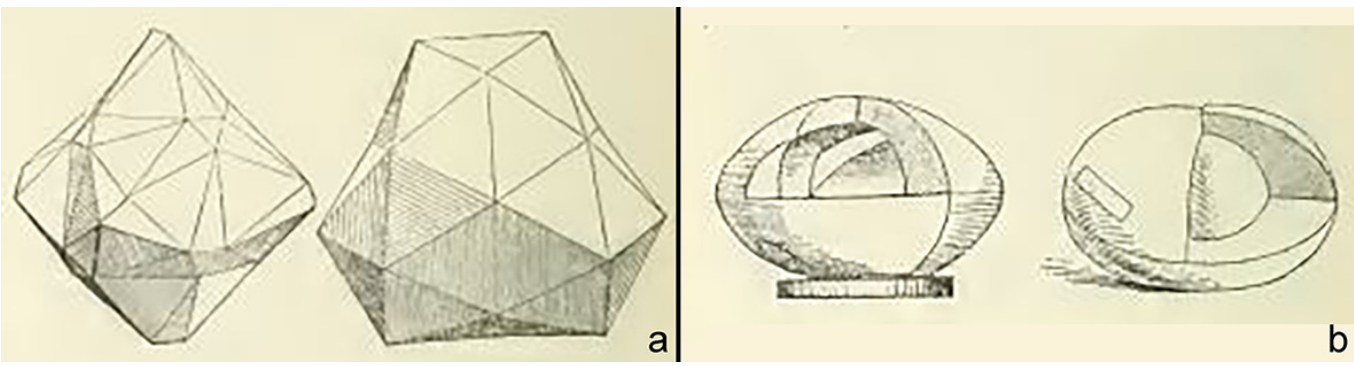

creare un atlante di rappresentazioni di modelli matematici la cui visualizzazione attraverso il disegno non era codificata. La scelta di non rappresentare tutti i modelli a catalogo, ma solo quelli ritenuti significativi segue le finalità comunicative e le problematiche sulla classificazione degli enti geometrici che caratterizzarono la ricerca matematica del tempo. Per esempio, la famiglia di superfici cubiche della serie VII è rappresentata da un solo modello a p. 83. In fig. 9 si riconoscono la superficie diagonale di Clebsch con 27 rette reali (VII, I) rappresentata sul catalogo e molti altri modelli di superfici cubiche singolari descritti a sole parole.
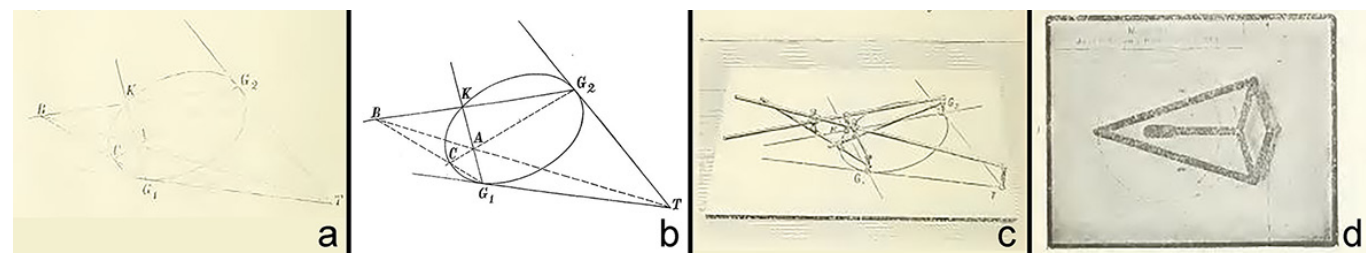

\section{Conclusioni}

La ricerca ha permesso di evidenziare le connessioni tra le necessità pratiche del catalogo, le caratteristiche sintetiche delle immagini iconiche dei modelli e il linguaggio matematico, scritto e visuale, che ne caratterizza la struttura. Stante il fatto che tra i vari modelli di superfici algebriche si inseriscano anche macchine per il disegno, è chiaro che tutti gli artefatti presentati diventano dei veri e propri attori di quei 'teatri didattici' animati da modelli tesi alla visualizzazione di oggetti matematici (e fisici) [Gay 2000, pp. 43-47]. Con la schedatura sistematica delle rappresentazioni simboliche del catalogo abbiamo messo in luce le valenze comunicative della pubblicazione: non solo strumento di promozione, ma vero e proprio medium di esposizione di oggetti matematici con un risvolto visuale sul Pensiero Visivo. Le immagini si sono rivelate iconiche tanto quando dedotte da fotografie che quando esito innegabile di una sintesi grafica poco attenta al risultato finale. Esse divengono elemento caratteristico del catalogo, filo del racconto visuale tessuto da un intreccio la cui trama sono le immagini stesse e l'ordito il testo descrittivo. Al momento non è stato possibile risalire agli autori delle stesse, né ai progetti dei modelli rappresentati, ma intendiamo proseguire la ricerca in questa direzione [6]. 
Fig. 9. Famiglia di superfici cubiche: a, b) superficie di Clebsch (p. 83) e relativo modello in gesso; $c, t)$ superfici cubiche (Biblioteca Peano, UniTo).
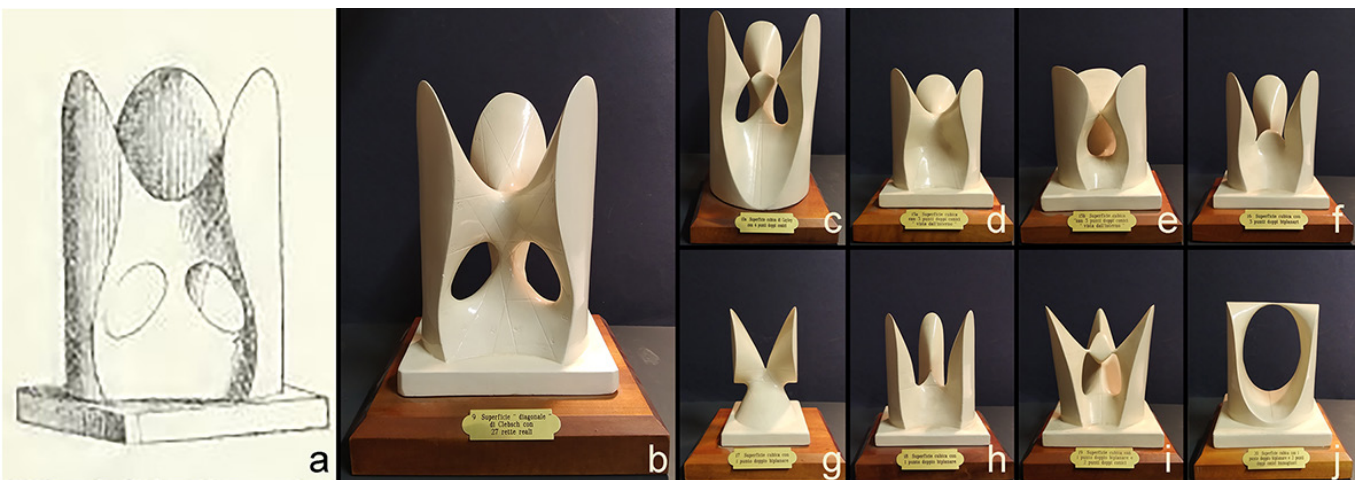

a
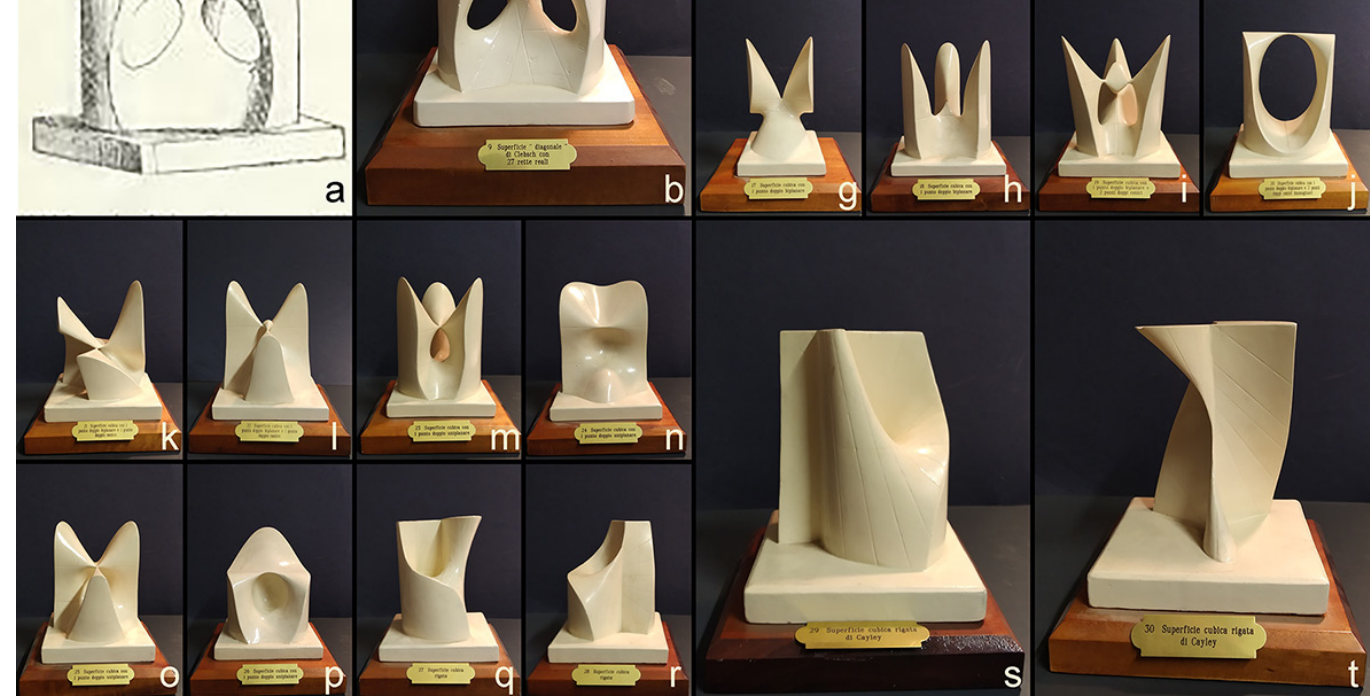

\section{Note}

[I] Per un elenco di cataloghi precedenti vedi Neuwirth 2014.

[2] Si confronti con il percorso avviato con l'analisi del modello fisico in qualità di generatore di immagini sintetiche delle proprie geometrie [Pavignano et al. 2020].

[3] In un numero della rivista Monatsberichte der K. Preussischen Akademie der Wissenschaften zu Berlin.

[4] A proposito di un modello della collezione di Besançon, Neuwirth [2014] annota "le modèle gauchit ces droites, ce qui a incité Claus Michael Ringel à commissionner un nouveau plâtre à Friedhelm Kürpig, sur lequel les droites sont réellement droites".

[5] Per maggiori dettagli sulla collezione di modelli della Biblioteca "G. Peano" di Torino, si veda [Giacardi 2003]. Per un elenco dei modelli richiesti da L. Campedelli per reintegrare la collezione post danni bellici, si veda [BUMI I952]. La collezione UniTo è solo una tra le molte nel mondo. Tra le più importanti, costituite in varia misura da modelli fisici e virtuali, ricordiamo quelle delle Università di Gröningen, Tübingen, Harward, MIT, Padova, Napoli e Paris VI [Weiss 2019, p. I07; Fisher 20 I7].

[6] Per M. Pavignano e U. Zich il contributo è stato sviluppato nell'ambito del progetto di ricerca MAG.IA 20I9. C. Cumino è membro del Gruppo Nazionale per le Strutture Algebriche, Geometriche e le loro Applicazioni (GNSAGA-INDAM).

\section{Riferimenti bibliografici}

Apéry François (2012). Old and New Mathematical Models: Saving the Heritage of the Institut Henri Poincaré. In Bruter Claude (ed.). Mathematics and Modern Art. Proceedings of the First ESMA Conference. Paris, July 19-22, 20 I0, pp. 17-27. BerlinHeidelberg: Springer.

Betsch Gerard (20I8). Zur Geschichte der Mathematischen Modelle. Von der Renaissance bis heute. Seidl Ernst, Loose Frank, Bierende Edgar (eds.). Mathematik mit Modellen. Alexander von Brill und die Tübinger Modellsammlun,. Tübingen: Museum der Universität Tübingen MUT, pp. 69-90.

BUMI 1952. Bollettino dell'Unione Matematica Italiana, 3, 7, pp. 459-484.

Bortot Alessio (2019). Superfici parametriche: modelli matematici, geometrici e artistici. In Belardi Paolo (a cura di). Riflessioni. L'arte peril disegno. II disegno per l'arte. Atti del $41^{\circ}$ Convegno Internazionale dei Docenti delle Discipline della Rappresentazione. Perugia 19-20-2I settembre 2019, pp. 417-424. Roma: Gangemi.

Farinella Cristian, Baglioni Leonardo (2017). Modello come immagine mentale. La diffusione dei modelli matematici nell'arte d'avanguardia e la superficie sviluppabile di Antoine Pevsner. In Di Luggo Antonella et al.Territori e frontiere della rappresentazione. Atti del $39^{\circ}$ Convegno Internazionale dei Docenti delle Discipline della Rappresentazione. Napoli |4, I5, I6 settembre 20 I7, pp. 929-936. Roma: Gangemi. 
Fischer Gerd (ed.). (2017). Mathematical Models. From the Collections of Universities and Museums. Wiesbaden: Springer Spektrum. (Prima edizione: Mathematische Modelle. Aus den Sammlungen von Universitäten und Museen. Braunschweig: Friedric Vieweg and Sohn, 1986)

Friedman Michael (20।8). A History of Folding in Mathematics. Mathematizing the Margins. Basel: Birkhäuser.

Gay Fabrizio (2000). Intorno agli omolografi. Strumenti e modelli per la geometria descrittiva. Venezia: IUAV.

Giacardi Livia (20 I 5). Geometric Models in Mathematics Teaching in Italy at the Turn of the Twentieth Century. In Mathematisches Forschungsinstitut Oberwolfach, 47, pp. 2784-2787.

Giacardi Livia (2003). La collezione di modelli geometrici della Biblioteca speciale di Matematica "G. Peano". In Giacobini Giacomo (a cura di). La memoria della scienza. Musei e collezioni dell'Università di Torino. Torino: Alma Universitas Taurinensis, pp. 25I-266.

Greco Lorena, Rossi Maria Laura, Salvatore Marta (20I8). About the 'Cape'. Considerations on Geometries of the Maurizio Sacripanti's Osaka Pavilion Roof. In Diségno, 2, pp. 77-88.

Klein Felix (1872). Vergleichende Betrachtungen über neuere geometrische Forschungen. Erlangen: Deichert: <http://www. deutschestextarchiv.de/book/show/klein_geometrische_|872>.

Marchis Vittorio (2008). Storie di cose semplici. Milano: Springer.

Mattheis Martin (2019). Aspects of "Anshauung" in the work of Felix Klein. In Weingand Hans-Georg et al. (ed). The legacy of Felix Klein, pp. 93-106 Cham: Springer: <https://doi.org/10.1007/978-3-319-99386-7>.

Neuwirth Stefan (2014). Objets mathématiques du laboratoire de mathématiques de Besançon. Catalogue de l'exposition des objets mathématiques du laboratoire de mathématiques de Besançon au Musée du temps de Besançon, de novembre 2013 à juin 2014. Milano: Silvana.

Palladino Franco, Palladino Nicla (200I). Sulle raccolte museali italiane di modelli per le matematiche superiori. Catalogo generale e sito web. In NUNCIUS - Annali dell'Istituto e Museo di Storia della Scienza di Firenze, XVI, pp. 78I-790.

Palladino Franco, Palladino Nicla (2009). I modelli matematici costruiti per l'insegnamento delle matematiche superiori pure e applicate. In Ratio Mathematica, 19, pp. 31 -88

Pavignano Martino, Zich Ursula, Cumino Caterina, Spreafico Maria Luisa, Bucolo Ornella, Miron Daniela (2020). Direct and Indirect Geometry of Architectural Paper Model. Images for Imagination. In Cicalò Enrico (ed.). Images for Imagination. Proceedings of IMG 2019 Graphics, Alghero 3-5 luglio 2019. Cham: Springer, pp. I | 4- I 27 <https://doi.org//0.1007/978-3030-41018-6_12.>

Rowe David E. (1985). Felix Klein's “Erlanger Antrittsrede”. In Historia Mathematica, I2, pp. I23-I4I.

Schilling Martin (1903). Catalog mathematischer Modelle für den höheren mathematiscen Unterricht. Halle: Martin Shilling.

Schilling Martin ( $19 \mid$ I). Catalog mathematischer Modelle für den höheren mathematiscen Unterricht. Leipzig: Martin Shilling.

Seidl Ernst (20 18). Die Modelle, Brill und das studentische Projekt. In Seidl Ernst, Loose Frank, Bierende Edgar (ed.). Mathematik mit Modellen. Alexander von Brill und die Tübinger Modellsammlun.Tübingen: Museum der Universität Tübingen MUT, pp. I 9-33.

Seidl Ernst, Loose Frank, Bierende Edgar (eds.). (20l8). Mathematik mit Modellen. Alexander von Brill und die Tübinger Modellsammlung. Tübingen: Museum der Universität Tübingen MUT.

Vierling-Claassen Angela (2007). Mathematical Models at the Massachusetts Institute of Technology. A working catalogue: <www. academia.edu/3 I570834/Mathematical_Models_at_the_Massachusetts_Institute_of_Technology>.

Weiss Ysette (2019). Introducing History of Mathematics Education Through Its Actors: Peter Treutlein's Intuitive Geometry In Weingand Hans-Georg et al. (eds.) The legacy of Felix Klein, pp. 107- I 6 Cham: Springer: <https://doi.org// 0. I007/978-3-

\section{Autori}

Martino Pavignano, Politecnico di Torino, martino.pavignano@polito.it

Caterina Cumino, Politecnico di Torino, caterina.cumino@polito.it

Ursula Zich, Politecnico di Torino, ursula.zich@polito.it

Per citare questo capitolo: Pavignano Martino, Cumino Caterina, Zich Ursula (2020). Catalog Mathematischer Modelle. Connessioni tra testo, rappresentazione grafica e descrizione analitica/Catalog Mathematischer Modelle. Connections between text, graphic representation and analytical description. In Arena A., Arena M., Brandolino R.G., Colistra D., Ginex G., Mediati D., Nucifora S., Raffa P. (a cura di). Connettere. Un disegno per annodare e tessere. Atti del $42^{\circ}$ Convegno Internazionale dei Docenti delle Discipline della Rappresentazione/Connecting. Drawing for weaving relationships. Proceedings of the 42th International Conference of Representation Disciplines Teachers. Milano: FrancoAngeli, pp. 3660-3677. 


\title{
Catalog Mathematischer Modelle. Connections between Text, Graphic Representation and Analytical Description
}

\author{
Martino Pavignano \\ Caterina Cumino \\ Ursula Zich
}

Abstract

Our contribution analyzes the Catalog Mathematischer Modelle, published by Schilling in 1903, in its double meaning of catalog: of mathematical models and of images of the models themselves. This work is a first outcome of the critical reading of a graphic/textual/analytical source started with an interdisciplinary approach, investigating physical models as a geometric, haptic and visual language common to Architecture and Mathematics.

The catalog represented, for the sale of mathematical models, a new type of systematization compared to similar examples published in the previous twenty years, in that it proposed a presentation of information by classification and not only by product innovation to be placed on the market, thus mediating its role as reference sales catalog for the choice of visual aids for Mathematics education. The socio-scientific context and the analysis, basically visual, not only of the tools chosen for the representation, but also of the editorial dynamics, led to critically reading the catalog as a medium of communication of mathematical results with a visual implication on Visual Thinking in the belonging matter, thus investigating its connections with written images and drawn words and a glance towards the real object, between physical and digital collections.

Keywords

Communication of Geometry, physical models, mathematical objects, geometry of algebraic surfaces, Brill-Schilling.
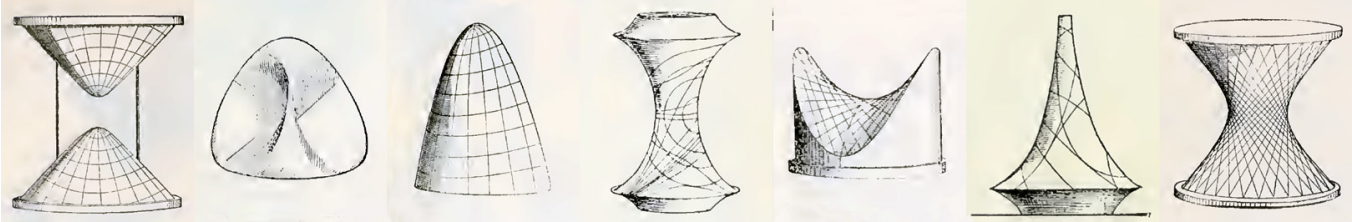

Catalog mathematischer Modelle
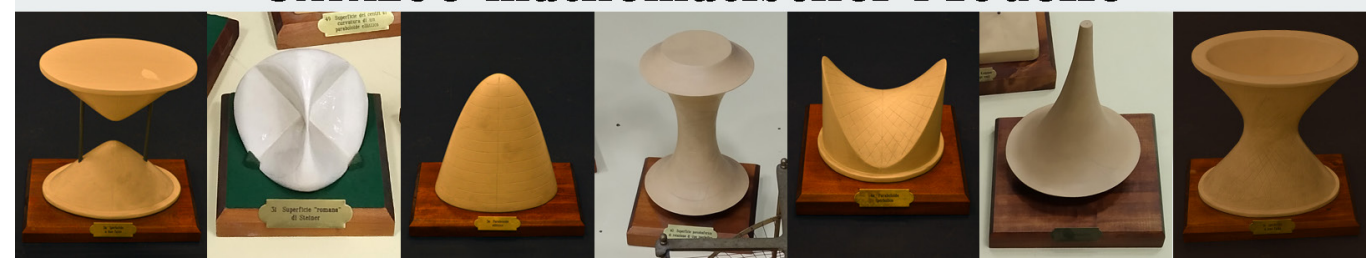


\section{Introduction}

The contribution, part of a multidisciplinary research project analyzing the application connections between Mathematics and Architecture by means of the common language of geometry and with particular focus on the use of physical models in the two disciplines, proposes an analysis of the communication dynamics relating to the 1903 edition of the Catalog Mathematischer Modelle published by Martin Schilling.This catalog was a commercial promotional tool of visual aids for the study of problems belonging to the most varied areas of mathematical thought [Schilling 1903, p. III], with a new systematization typology compared to similar catalogs published in the previous twenty years [I]. The connections between these models and their representations through written images and drawn words are investigated [2].

Fig. I. Advertising by the publisher Brill pring 189. a) Archiv prothematik und Physik, 61, 336, 1877; b) Mathematisch Annalen, 15, 3-4, 1879 c) Mathematische Annalen, 18, 3, 1881; d) American Journal of Mathematics, 12 , 3, 1890 [Seidl et al. 2018, pp. I| $3,116,255,99]$.
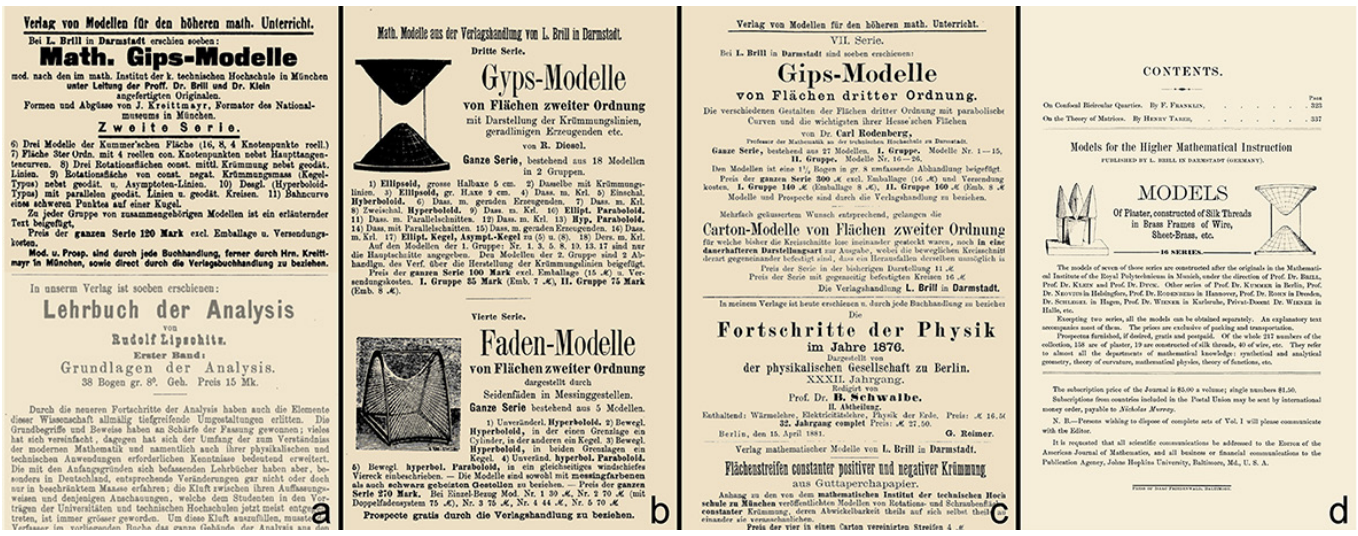

\section{Geometric models}

In Mathematics, the visual use of spatial models dates back at least to Luca Pacioli's studies on platonic solids [Betsch 20I8, pp. 70,7l], but a first reference to the use of physical models dates back to 1863 [Giacardi 2003, p. 25 I].

In the mid-nineteenth century, particularly in Germany, progress in the study of Geometry led to the construction of physical models of algebraic surfaces, curves and other mathematical objects starting from their equations [Palladino, Palladino 200 I].

One of the proponents of the models production was Felix Klein who, together with Alexander von Brill, set up a laboratory for design and construction on an artisanal scale in Munich [4].The models were built with poor materials, but their eidetic potential allowed their use to illustrate very complex considerations or calculations, difficult to describe in terms of simple language [Gay 2000, pp. 43-52], materializing an immaterial construct of ideas, connecting the abstract system of codified signs that could describe them to a tangible artifact [Seidl 20।8, p. 20].

According to Klein they were a useful visual aid [Giacardi 20 I5], to show the research progress and to stimulate new investigations [Klein 1872]. The model was not an end in itself, but worked as an epistemic procedure: with its production and relations with the family of objects to which it belonged, it indicated new types of knowledge [Friedman 20 I 8].

Furthermore, for Klein spatial intuition was also fundamental in the process of modernizing Mathematics teaching, to "strengthen the ability to think in three dimensions and the habit of functional reasoning" and to improve teacher training, through maths seminars and exercises on drawing and model building [Mattheis 2019, p. 93; Rowe 1985, p. I 39]. Models potential soon became evident and, in order to spread the sale, the Ludwig Brill publishing house was founded in Darmstadt and a catalog was prepared for their advertising [Giacardi 2003], promoting it in important mathematical journals (fig. I). 
In 1899, Brill firm was replaced by that of Martin Schilling from Halle who continued the publication, starting from the sixth edition of the catalog, while the systematic work of the various models series was carried out with the scientific collaboration of many mathematicians, including Ludwig Wiener and Herman Wiener [Schilling 1903, p. III]. Models spread left also mathematics field: many models were generators of compositional suggestions, especially for avant-garde architects and designers [Bortot 20 I9; Greco et al. 20 I 8; Farinella, Baglioni 2017].

In the 1930s, production ran out: the growing abstraction and generalization of mathematical thinking meant that research objects could no longer be viewed with 3D models. Only towards the end of the twentieth century was the concept of visualization in Mathematics recovered, thanks to the progress of computer science, through virtual images and therefore potentially concrete objects [Palladino 2009] and a renewed attention to the "material dimension of ideas" [Marchis 2008, p. 170]: but, despite the evolution of languages and methods, it is still essential being able to develop a mental image of a mathematical object starting from a concrete example [Apery 20 I2].

\section{The Schilling Catalog 1903: analysis}

By Schilling's own declaration, the 1903 catalog presents itself as the evolution of the previous one with the explicit intention of better organizing its contents in two distinct parts. Part I presents the models in order of publication, series and number, Part II arranges them systematically providing an overview of their mathematical contents.

The catalog therefore replaces the previous ones, becoming a supporting structure for the following, constituting a cataloging of the scientific haptic aids whose systematizes data (series and number at the time of the first publication, material, size, price, mathematical classification) making their sharing more accessible, for univocal identification and connections between the different specific contents of the sections. The difference between the two is further underlined by the layout choices: I text column in Part I presenting a single image (fig. 2b); 2 text columns in Part II, with the exception of the few introduction lines to the specific part (fig. 2c), containing 78 images of the 321 described models and 2 images of their supports (80 in total).

Fig. 2. Layout examples of the Catalog Mathematscher Modelle, 1903.

a, b) Parte I, pp. 61,66;

c, d) Parte II, pp. 79, 80
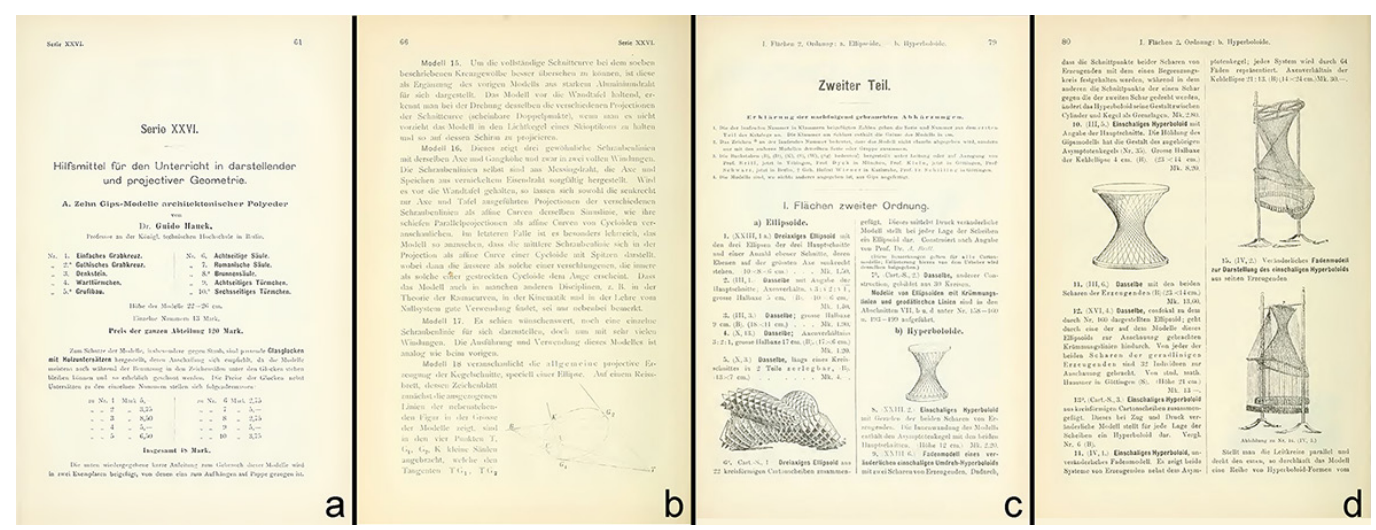

The catalog has been analyzed not only as such [Vierling-Claassen 2007], but as a corpus of models images investigating their semantic and synthetic values, also in relation to the real object that we verified with the collection of the "G. Peano" Library of the Mathematics Department of the University of Turin [5]. 


\section{From catalog of mathematical models to catalog of mathematical models images}

The systematic reading of the iconographic apparatus was set up with a cataloging that summarizes the characteristics of: layout, textual description and correlation with it, communicative values in the choice of tools and codes of representation. In constructing the cataloging, where the graphic quality of the reference source seemed inadequate to the considerations in question, the illustrations of the subsequent editions were compared and, in the case of perfect correspondence, these images were also acquired (fig. 8a, 8b).

Images insertion in text does not follow a rigid scheme: they are inserted before the model name, within the description or on the next page; only 9 have a caption.

The layout of the Part II is set on two columns and of the 80 images present only 2 occupy both, 5 are slightly exceeding (fig. 6c) and all the others are smaller than the column width leaving wide margins (fig. 3). Figure 4 summarizes all the images extracted in sequence from the catalog while maintaining the same reduction scale to allow a direct visual comparison. Representation scale is not specified in drawings, but models dimensions are always expressed in the relative texts.

Representation on p. 98 shows two distinct objects belonging to the same group of 8 wire models. The 3D views present the models as a visual and haptic synthesis of the mathematical description of a skew curve (metal wire) in a reference system defined by three orthogonal planes; the possibility of moving one's point of view and observing the wire projection on the planes makes the model interactive, inducing an immediate correlation between

\begin{tabular}{|c|c|c|c|c|}
\hline $\begin{array}{l}80 \\
\text { Immagini } \\
\text { Images }\end{array}$ & $\begin{array}{l}1 \\
\text { Colonna } \\
\text { Column }\end{array}$ & $\begin{array}{l}2 \\
\text { Colonna } \\
\text { Column }\end{array}$ & $\begin{array}{l}\text { EXTRA } \\
\text { Extra Colonna } \\
\text { Extra Column }\end{array}$ & TOT \\
\hline $\begin{array}{l}\text { S } \\
\text { Singola } \\
\text { Single }\end{array}$ & 62 & & 4 & 66 \\
\hline $\begin{array}{l}\text { D } \\
\text { Doppia } \\
\text { Double }\end{array}$ & 2 & 1 & & 3 \\
\hline $\begin{array}{l}\text { G } \\
\text { Gruppo } \\
\text { Group }\end{array}$ & 3 & 1 & & 4 \\
\hline $\begin{array}{l}\text { M } \\
\text { Macchina per disegnare } \\
\text { Drawing Machine }\end{array}$ & 4 & & 1 & 5 \\
\hline $\begin{array}{l}\text { B } \\
\text { Base per modelli } \\
\text { Models Base }\end{array}$ & 2 & & & 2 \\
\hline TOT & 73 & 2 & 5 & 80 \\
\hline
\end{tabular}


Fig. 4. Matrix of the 80 illustrations of

Mathematischer Modelle 1903.

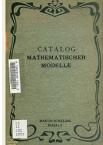 \\ $2 \times \leq \&$}

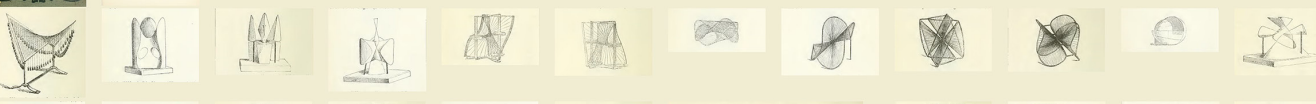

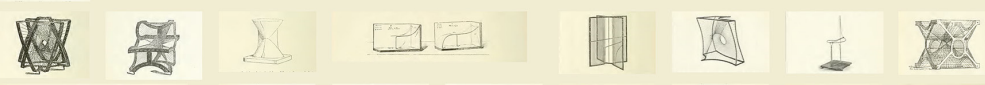

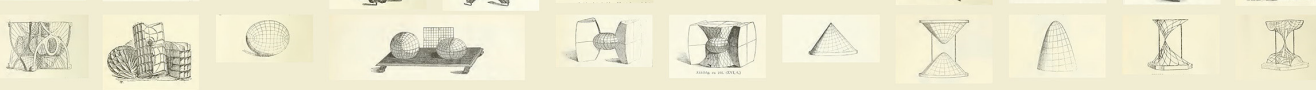

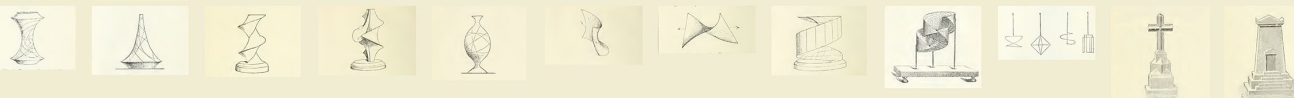

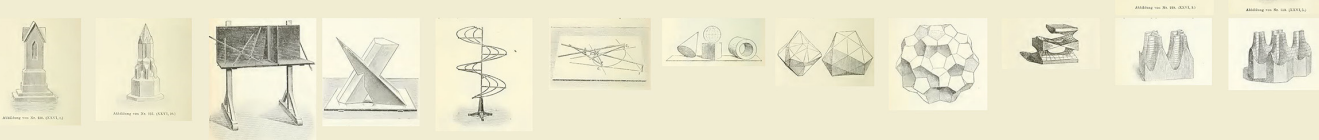

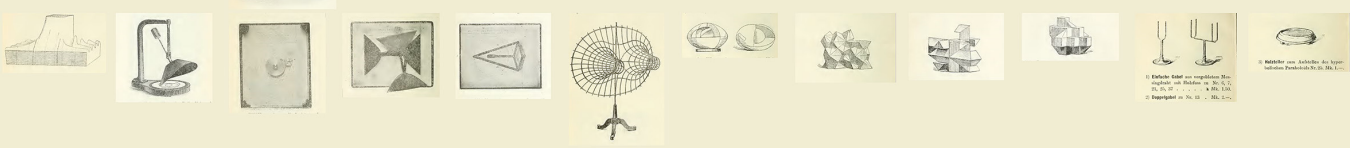

Fig. 5. Skew curves orthotion to their

) Schillin 1903 .

b) Brill 1885, p. 38 .

b) Brill 1885, p. 38;

c, d) pictures of the

the collection of the

University of Tübingen

Seidl et al. 2018, pp. 278
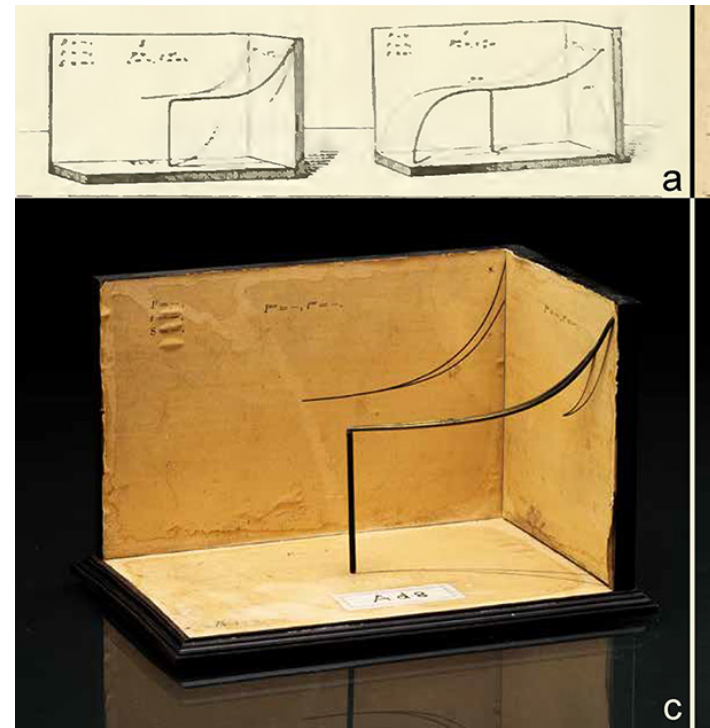
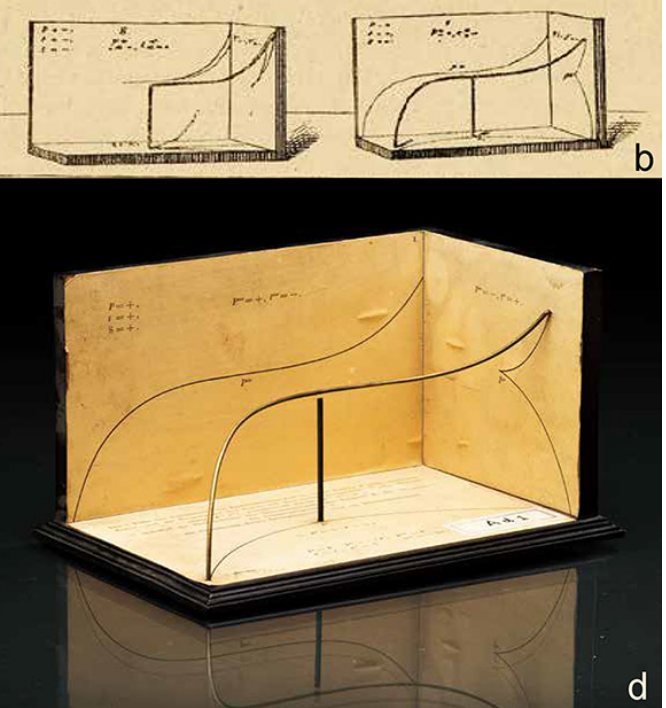
singularities of the curve and singularities of its projections. Photographic images of models belonging to collections that can now be visited online allow one to grasp further details of the wire layout in regard to the planes on which not only the orthographic projections but also texts and analytical indications are given (fig. 5).

Models XVI, I-3 are shown on the wooden support with which they are sold as a group to maintain their connections (fig. 6b). Another 3 group images are inserted in a single-width column (see pp.79, II 3 and 102), (fig. 6a).

The remaining 73 images are inserted in a text column and only 3 contain 2 representations simultaneously: on pp. I | 8, I 30 we find representations of 2 different objects referable to the same description (fig. 7a), while on p. 126 the image shows two views of the same object, one in orthographic projection and one three-dimensional, perhaps with the intention of showing the possibility of disassembling the model to observe its interior (fig. 7b). The only model XXVI, I 8 is represented twice, once in Part I on p. 66 occupying $2 / 3$ of the column and one in Part II, on p. I 6 (fig.8a, 8c). Its uniqueness in the catalog finds possible

Fig. 6. Layout examples: a) XXII, I-3, p. I02 b) XVI, I-3, p. I03; c) images that occupy the space between the columns of text and the lateral margins, p. I I5.
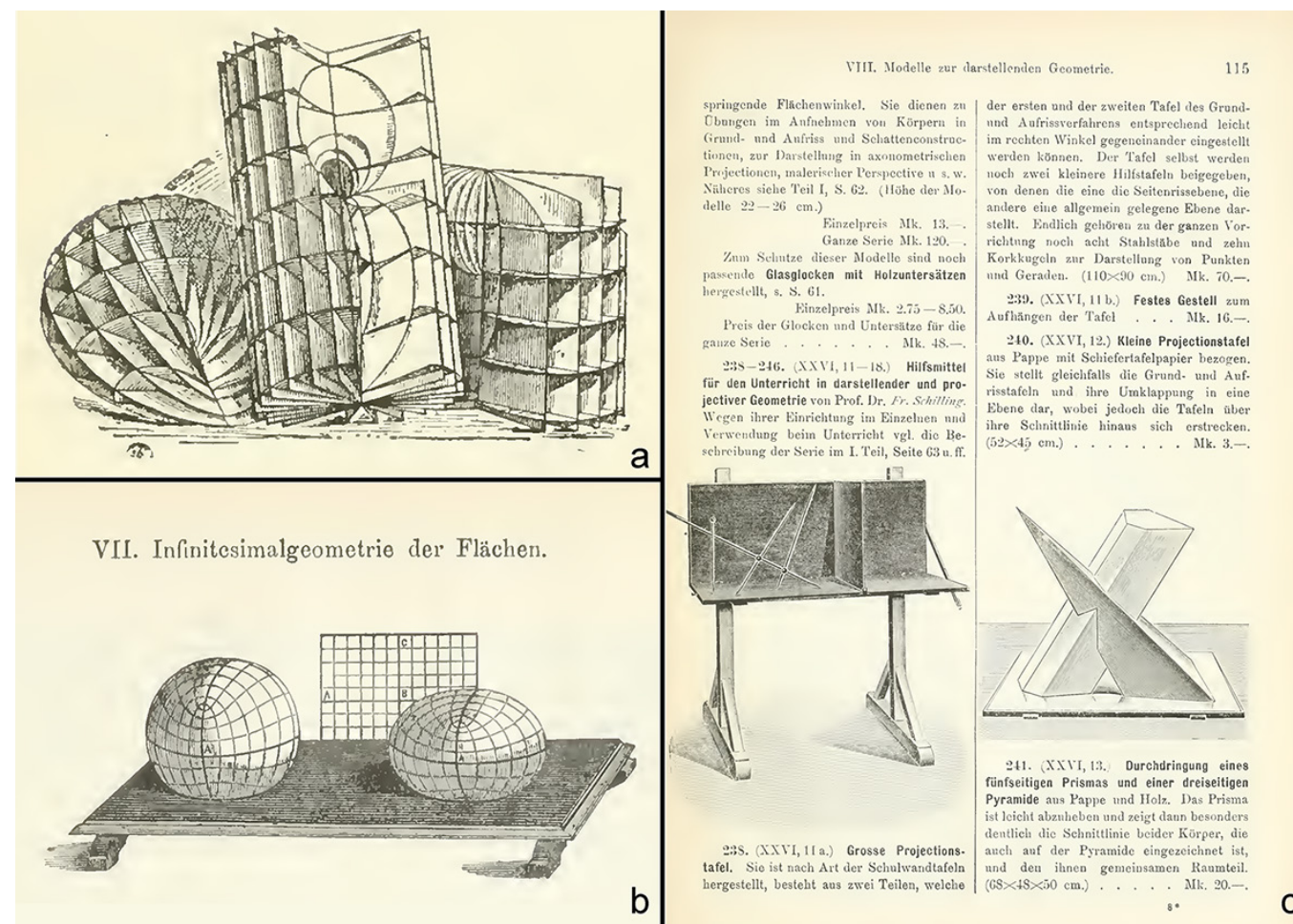

interpretation in the intention of illustrating "the general projective generation of conic sections, in particular an ellipse", or the operation of the drawing machine, going beyond the mere material description. The technical description (fig. 8b) uses different types of lines and letters to identify points and the author reminds that, in the design intention of creation and dissemination of mathematical models as didactic visual aids, "when building the models, particular attention is paid to ensuring that the technical parts do not obscure the mathematical idea" [Schilling 1903, p. 67]. Instead, textual indications of p. II 6 (fig. 8c) are essential and perspective summarizes machine three-dimensionality and the outcome of its use: the shadows highlight structure volume and the total absence of what it would project on the sheet suggests reading the image as a synthetic, not descriptive, symbolic representation in favoring the content and not necessarily its perfect correspondence with reality: instrument shadow would have severely limited the reading of its product during use. With these in- 
Fig. 7. Matched images: a) $X V, 8-12$, p. 118 b) VI, I, p. 126.
Fig. 8. 'Drawing machines' a) Schilling 1903, p. 66 b) Schilling 1911, p. 67; c) Schilling 1903, p. 116 ; d) Schilling 1903, p. 125 , tentions, on some occasions (pp. 124, 125), photography was used (fig. 8d), a tool further implemented in subsequent editions.

Therefore we find descriptive and symbolic representations, geometrically constructed and non-geometrically constructed drawings, 3D views and projection planes, pictures and drawings constructed as a tracing of them: a vast diversified panorama of images that combine to create a representations atlas of mathematical models whose visualization through the drawing was not codified. The choice not to represent all the models in the catalog but only those deemed significant follows the communication purposes and the problems
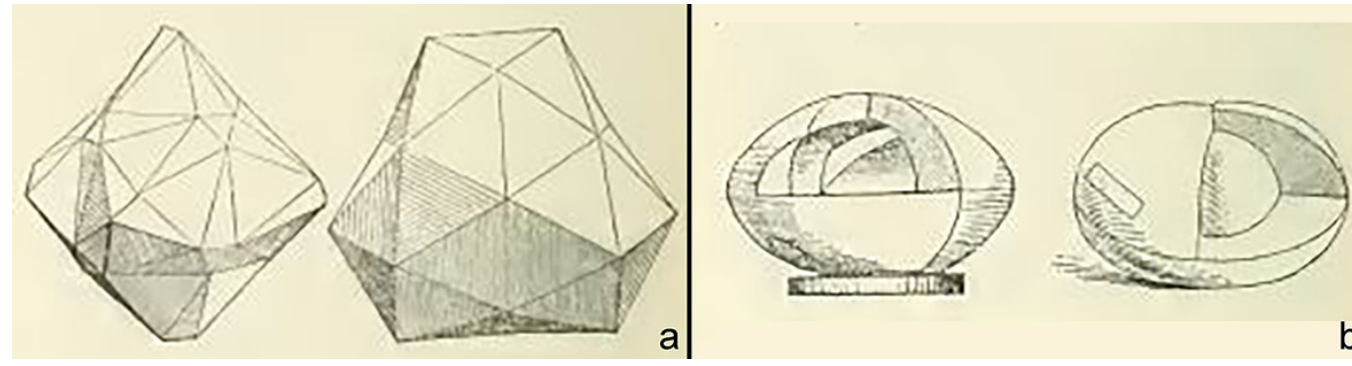

b

regarding geometric entities classification that characterized the mathematical research of the time. For example, the family of cubic surfaces of the VII series is represented by a single model on p. 83. In fig. 9 we can recognize the diagonal Clebsch surface with 27 straight lines (VII, I) shown in the catalog and many other models of singular cubic surfaces described only in words.

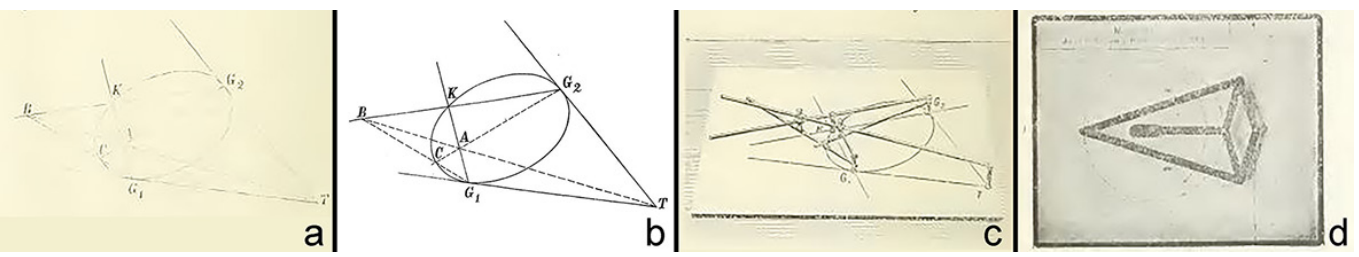

\section{Conclusions}

The research allowed to highlight connections between catalog practical needs, synthetic characteristics of the models iconic images and mathematical language, written and visual, which characterizes its structure. Among the various models of algebraic surfaces there are also drawing machines and it is clear that all the artifacts presented become real actors of those "didactic theaters" animated by models aimed at visualizing mathematical (and physical) objects [Gay 2000, pp. 43-47]. With the systematic cataloging of the catalog symbolic representations, we highlighted the communicative values of the publication: not only a promotional tool, but a real medium for displaying mathematical objects with a visual implication on Visual Thinking in the matter to which they belong. Images turned out to be iconic both when deduced from pictures and when undeniable results of a graphic synthesis that pays little attention to the final result. They become a characteristic element of the catalog, thread of the visual story woven by an interweaving whose weft are the images themselves and the warp the descriptive text. At the moment it was not possible to trace models authors, nor their projects, but we intend to continue the research in this direction [6]. 
Fig. 9. Family of cubic surfaces: a, b) Clebsch surface (p. 83) and relative plaster model; $c$ t) cubic surfaces (Peano Library, UniTo).
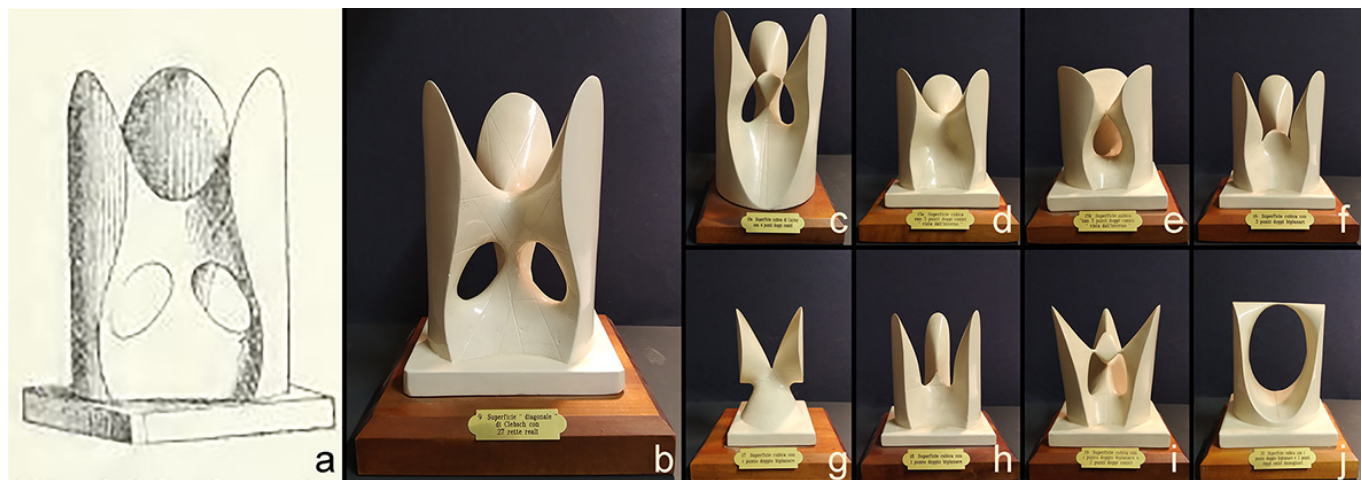

a
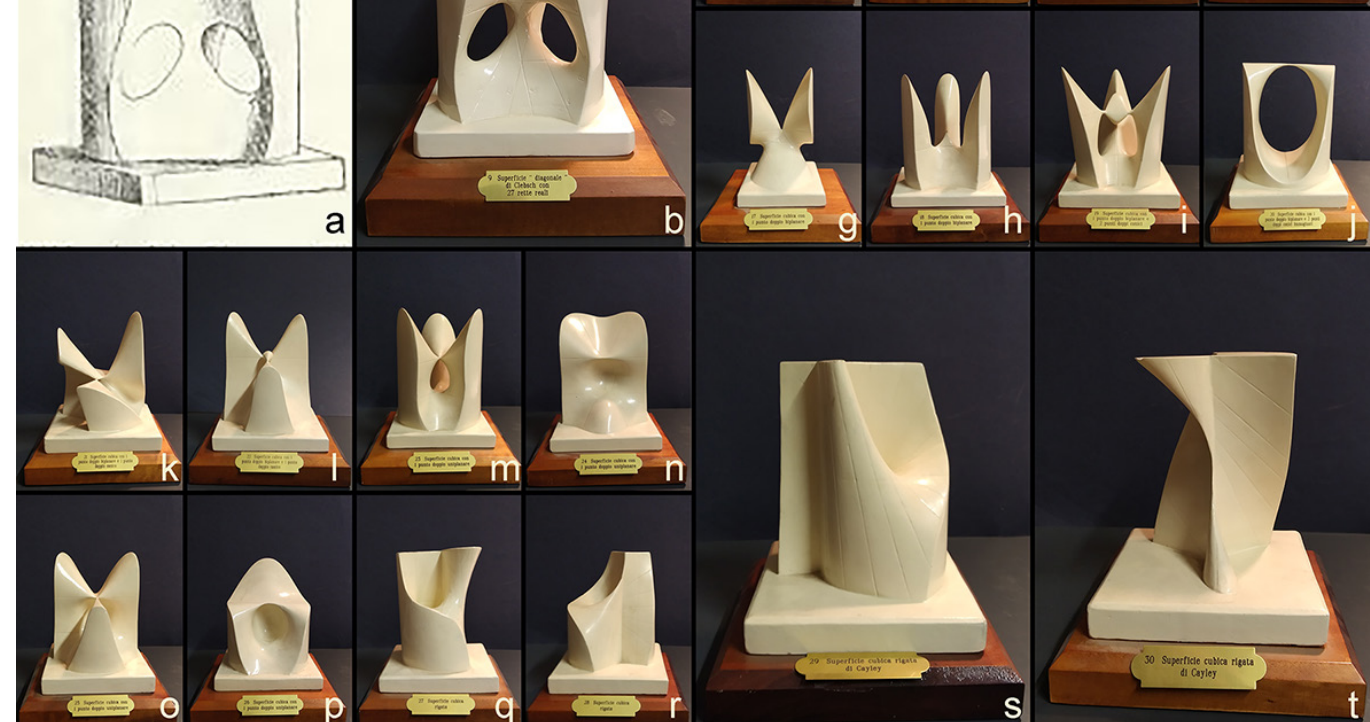

Notes

[I] For a list of previous catalogs: Neuwirth 2014.

[2] Compare with the path started through the analysis of physical model as a generator of synthetic images of its geometries [Pavignano et al. 2020].

[3] In an issue of the magazine Monatsberichte der K. Preussischen Akademie der Wissenschaften zu Berlin.

[4] About a model from the Besançon collection, Neuwirth [2014] notes "le modèle gauchit ces droites, ce qui a incité Claus Michael Ringel à commissionner un nouveau plâtre à Friedhelm Kürpig, sur lequel les droites sont réellement droites".

[5] For more details on "G. Peano" Library of Turin, see [Giacardi, 2003]. For a list of models requested by L. Campedelli to reintegrate the collection after war damage, see [BUMI 1952]. The UniTo collection is just one of many in the world. Among the most important ones, made up in various ways of physical and virtual models, we remember those of the Universities of Gröningen, Tübingen, Harward, MIT, Padova, Napoli e Paris VI [Weiss 2019, I07; Fisher 20 I7].

[6] M. Pavignano and U. Zich the contribution was developed within the research project M.A.G.I.A. 20I9: Mathematics Architecture Geometry. Interconnections and Applications, 20 19. C. Cumino is member of the National Group for Algebraic and Geometric Structures, and their applications (GNSAGA-INDAM).

\section{References}

Apéry Francois (2012). Old and New Mathematical Models: Saving the Heritage of the Institut Henri Poincaré. In Bruter Claude (ed.). Mathematics and Modern Art. Proceedings of the First ESMA Conference. Paris, July 19-22, 20 I0, pp. I7-27. BerlinHeidelberg: Springer.

Betsch Gerard (2018). Zur Geschichte der Mathematischen Modelle.Von der Renaissance bis heute. Seidl Ernst, Loose Frank, Bierende Edgar (eds.). Mathematik mit Modellen. Alexander von Brill und die Tübinger Modellsammlun,. Tübingen: Museum der Universität Tübingen MUT, pp. 69-90.

BUMI 1952. Bollettino dell'Unione Matematica Italiana, 3, 7, pp. 459-484.

Bortot Alessio (2019). Superfici parametriche: modelli matematici, geometrici e artistici. In Belardi Paolo (a cura di). Riflessioni. L'arte peril disegno. II disegno per l'arte. Atti del $41^{\circ}$ Convegno Internazionale dei Docenti delle Discipline della Rappresentazione. Perugia 19-20-21 settembre 2019, pp. 417-424. Roma: Gangemi.

Farinella Cristian, Baglioni Leonardo (2017). Modello come immagine mentale. La diffusione dei modelli matematici nell'arte d'avanguardia e la superficie sviluppabile di Antoine Pevsner. In Di Luggo Antonella et al.Territori e frontiere della rappresentazione. Atti del $39^{\circ}$ Convegno Internazionale dei Docenti delle Discipline della Rappresentazione. Napoli 14, I5, I6 settembre 2017 , pp. 929-936. Roma: Gangemi. 
Fischer Gerd (ed.). (2017). Mathematical Models. From the Collections of Universities and Museums. Wiesbaden: Springer Spektrum. (Prima edizione: Mathematische Modelle. Aus den Sammlungen von Universitäten und Museen. Braunschweig: Friedric Vieweg and Sohn, 1986)

Friedman Michael (20।8). A History of Folding in Mathematics. Mathematizing the Margins. Basel: Birkhäuser.

Gay Fabrizio (2000). Intorno agli omolografi. Strumenti e modelli per la geometria descrittiva. Venezia: IUAV.

Giacardi Livia (20 I 5). Geometric Models in Mathematics Teaching in Italy at the Turn of the Twentieth Century. In Mathematisches Forschungsinstitut Oberwolfach, 47, pp. 2784-2787.

Giacardi Livia (2003). La collezione di modelli geometrici della Biblioteca speciale di Matematica "G. Peano". In Giacobini Giacomo (a cura di). La memoria della scienza. Musei e collezioni dell'Università di Torino. Torino: Alma Universitas Taurinensis, pp. 25I-266.

Greco Lorena, Rossi Maria Laura, Salvatore Marta (20I8). About the 'Cape'. Considerations on Geometries of the Maurizio Sacripanti's Osaka Pavilion Roof. In Diségno, 2, pp. 77-88.

Klein Felix (1872). Vergleichende Betrachtungen über neuere geometrische Forschungen. Erlangen: Deichert: <http://www. deutschestextarchiv.de/book/show/klein_geometrische_|872>.

Marchis Vittorio (2008). Storie di cose semplici. Milano: Springer.

Mattheis Martin (2019). Aspects of "Anshauung" in the work of Felix Klein. In Weingand Hans-Georg et al. (ed). The legacy of Felix Klein, pp. 93-106 Cham: Springer: <https://doi.org/10.1007/978-3-319-99386-7>.

Neuwirth Stefan (2014). Objets mathématiques du laboratoire de mathématiques de Besançon. Catalogue de l'exposition des objets mathématiques du laboratoire de mathématiques de Besançon au Musée du temps de Besançon, de novembre 2013 à juin 2014. Milano: Silvana.

Palladino Franco, Palladino Nicla (200I). Sulle raccolte museali italiane di modelli per le matematiche superiori. Catalogo generale e sito web. In NUNCIUS - Annali dell'Istituto e Museo di Storia della Scienza di Firenze, XVI, pp. 78I-790.

Palladino Franco, Palladino Nicla (2009). I modelli matematici costruiti per l'insegnamento delle matematiche superiori pure e applicate. In Ratio Mathematica, 19, pp. 31 -88

Pavignano Martino, Zich Ursula, Cumino Caterina, Spreafico Maria Luisa, Bucolo Ornella, Miron Daniela (2020). Direct and Indirect Geometry of Architectural Paper Model. Images for Imagination. In Cicalò Enrico (ed.). Images for Imagination. Proceedings of IMG 2019 Graphics, Alghero 3-5 luglio 2019. Cham: Springer, pp. I | 4- I 27 <https://doi.org//0.1007/978-3030-41018-6_12.>

Rowe David E. (1985). Felix Klein's “Erlanger Antrittsrede”. In Historia Mathematica, I2, pp. I23-I4I.

Schilling Martin (1903). Catalog mathematischer Modelle für den höheren mathematiscen Unterricht. Halle: Martin Shilling.

Schilling Martin ( $19 \mid$ I). Catalog mathematischer Modelle für den höheren mathematiscen Unterricht. Leipzig: Martin Shilling.

Seidl Ernst (20 18). Die Modelle, Brill und das studentische Projekt. In Seidl Ernst, Loose Frank, Bierende Edgar (ed.). Mathematik mit Modellen. Alexander von Brill und die Tübinger Modellsammlun.Tübingen: Museum der Universität Tübingen MUT, pp. I 9-33.

Seidl Ernst, Loose Frank, Bierende Edgar (eds.). (20l8). Mathematik mit Modellen. Alexander von Brill und die Tübinger Modellsammlung. Tübingen: Museum der Universität Tübingen MUT.

Vierling-Claassen Angela (2007). Mathematical Models at the Massachusetts Institute of Technology. A working catalogue: <www. academia.edu/3 I570834/Mathematical_Models_at_the_Massachusetts_Institute_of_Technology>.

Weiss Ysette (2019). Introducing History of Mathematics Education Through Its Actors: Peter Treutlein's Intuitive Geometry In Weingand Hans-Georg et al. (eds.) The legacy of Felix Klein, pp. 107- I 16 Cham: Springer: <https://doi.org// 0. I007/978-3319-99386-7>

\section{Authors}

Martino Pavignano, Politecnico di Torino, martino.pavignano@polito.it

Caterina Cumino, Politecnico di Torino, caterina.cumino@polito.it

Ursula Zich, Politecnico di Torino, ursula.zich@polito.it

To cite this chapter. Pavignano Martino, Cumino Caterina, Zich Ursula (2020). Catalog Mathematischer Modelle. Connessioni tra testo, rappresentazione grafica e descrizione analitica/Catalog Mathematischer Modelle. Connections between text, graphic representation and analytical description. In Arena A., Arena M., Brandolino R.G., Colistra D., Ginex G., Mediati D., Nucifora S., Raffa P. (a cura di). Connettere. Un disegno per annodare e tessere. Atti del $42^{\circ}$ Convegno Internazionale dei Docenti delle Discipline della Rappresentazione/Connecting. Drawing for weaving relationships. Proceedings of the 42th International Conference of Representation Disciplines Teachers. Milano: FrancoAngeli, pp. 3660-3677. 